\title{
Using Innovations and Educational Technology Techniques to Deliver Educational Practicum and its effect on Increasing Academic Achievement among Pre-Service Teachers
}

\author{
Hatim Ibrahim 1 \\ ${ }^{1}$ Department of Educational Technology, College of Education, Imam Abdurrahman Bin Faisal University, P. O. Box 1982, \\ Dammam, 31441, Saudi Arabia. E-mail: hgmohsmed@iau.edu.sa.
}

\begin{abstract}
:
The aim of the current study is to determine the use of innovations and technology in education and its impact on the academic performing of teaching staff before service. The study sample was composed of (60) pre-service teachers of middle- and secondary schools randomly selected. The study adopted the descriptive method; a survey and observation cards tool for achieving the study goals. The study concluded that in educational training schools the availability of innovations and educational technology techniques was poor. It also demonstrated that there are challenges for student teachers to use innovations and techniques of educational technology.
\end{abstract}

Keywords:

educational, technology, Innovation, practicum, academic achievement.

Article Received: 18 October 2020, Revised: 3 November 2020, Accepted: 24 December 2020

\section{Introduction}

The world has undergone science and technology developments in recent decades, which have had a huge influence on everybody. The science of education techniques has therefore now been asked to investigate new educational approaches, models and techniques in order to overcome numerous problems that obstruct the education system. New educational innovations (e-learning, mobile teaching, interactive multimedia, high media, computer manuals, wireless devices) have contributed significantly to the advancement of educational techniques and education Theory.

Al-Kanadi (2005) states that in view of the advent and use of such technical advancement in education the position of students has changed. This means that students have become actively involved in the education process, searching for information, managing and engaging with printed and unprinted education materials. These technological innovations also affected academic courses and the contents, actions and ways in which they were submitted and evaluated. A key objective for these courses has been to instil the love of knowledge and to provide students with self-learning skills during the age of knowledge explosion. To this end, because of their advantages, a new revolution based on modern teacher techniques is necessary.

One of the essential and contemporary problems is the use of teaching technologies. Everyone knows that the fate of nations is related to their own citizens' ingenuity and their ability to adapt changes. Training is mainly a part of social change and one of the major winds of change, AlGhadeer states (2009). In addition to being able to rely on itself and promote self-education, the new education system found important positive aspects of modern techniques and educational models: a simulation of true life and the provision of a dual communication environment which controls and connects classrooms to the world. In order to attract students to targeted classes, to build a systemic and healthy interactive learning atmosphere, to achieve the concept of targeted training, which makes students aware of their needs, and to update the teaching system in ways that support teachers and students alike, according to Abdel-Megid (2000, which if delivered by random, will not achieve its purposes. Therefore 
teachers have to be trained to acquire field experience to help with the future of learners to reflect the greatness of this profession. Thus according Reiser (2002), those involved in educating their teachers almost agree on the importance of the field experience, which is also called field training or education.

Student teachers generally take training classes for a period of time determined by their school to be assured and gain trust. In such classrooms, student teachers learn about schools, their laws and their teachers, gain teaching experience and familiarise themselves with supervision, assessment method, criticism and assistance. This is in addition to strengthening their relationship with their colleagues. (Salem \& El-Halibi, 1998).

In this regards, field training is considered a method in which experts are supervised and guided to overcome the problems of education on the ground.

We have had to know about recent developments in this field because we recognised the importance of education and field experience both in developing and developed countries at all levels. In this connection, the Author tries to provide an overview of student teacher use of recent techniques and technology advances and their impact on the acquisition of knowledge and skills by students in a way that enables students to cope with such innovations. We therefore build a generation of teachers who can use these technologies effectively within an established educational system rather than teachers' random education (Atwa, 2001).

\section{Statement of the Problem}

The Author has found a substantial lack of use of advanced instructional technologies, and regardless of his experience in educative technology at the College of Special Education conventional approaches continue to prevail. The author considers that in addition to teacherlearning student-teachers who have fear of abandoning traditional methods and are not convinced by technological innovations, several causes include a shortage of teachers and professional experts, a lack of information about equipment management and a failure to plan . Furthermore the faculty and professor at the university, who oversees pre-school teachers for the third and fourth years, do not provide them with adequate expertises to use modern methods and techniques in computer courses and their relevant activities.

The author therefore reviewed student teachers' lecture plans booklets during the third and fourth years, during which time the work of pre-service teachers was supervised. He concluded that the methods of learning are limited to books, boards and cracks, and that there is no emphasis on teaching (techniques and materials). This indicates that modern educational technology technologies are difficult to use in the education process. Kotler (2001) says the new technology of educational communication (including computer, networking and satellite technology provides educational possibilities. In addition, schools that supply these new technologies lack certain power and resources. In view of the current requirements, however, students must be aware of certain techniques and uses to create a generation of teachers willing to recruit techniques and methods which address recent information and technology developments in education. These education technology strategies will replace a variety of conventional technologies currently employed in education. For example, you can access educational websites offering e-learning services by linking the device to the internet, radio, television and television stations. In addition to offering synchronous and asynchronous communication opportunities for the conventional recorder (Rad-Tell), advanced computers may replace specialized programmers for this reason.

The author further noted the lack of education technologies studies related to the development of the skills of student teachers graduating from the education technology division by means of an analysis of multiple studies and theoretical and field studies. In addition, such studies only concentrated on the use of traditional communication technologies in education. The 
author highlighted this issue, provided that the government is keen to provide education, in particular high and middle education and in recruiting new technologies and technology for education, and in view of its significance in training a generation of teachers who specialise in education technology at educational colleges and in education. The author also highlighted this problem. The research challenge is to identify how education-technology technologies and strategies are used in educational practise teaching and how they influence pre-service teacher academic success.

The author observes that students of pre-service use these strategies arbitrarily without knowledge of the skills needed to use them. The standard is either due to the supervisor of the faculty or to teacher supervisors or the secretary of labour, where students are trained as teachers.

\subsection{Questions}

The main question in the study:

What effect does the use of educational technology technologies and techniques by student teachers have on educational technology decision-making and their effects on the academic achievement among computer students? The following sub-questions arise from this issue.:

1. What are the innovations and techniques that can be used in educational practise in middle schools?

2. What is the degree to which innovations and techniques in education technology are accessible in middle schools?

3. What is the level of success in the use of educational technology technologies and techniques among student teachers in middle schools?

4. What are the challenges to using educational technology innovations and techniques in Saudi Arabia's secondary schools?

5. What skills do student teachers need to learn to use technical advances and strategies in middle schools?

\section{Objectives}

1. 1. Classifying the availability of technologies and techniques in educational technology in schools.

2. 2. Estimating the effect to which educational students use advances in education and technique.

3. Identify the barriers to the implementation of instructional technology innovations and techniques in middle school education..

4. 4. Recognizing the availability of the skills to use educational technologies and techniques for educational teachers in middle education.

\section{Significance}

The significance of the study lies in:

1. Taking advantage of the findings of the new study on the effective use of educational technology in virtual education.

2. Formulation of a generation of teachers of education technology ready to handle recent developments and teaching techniques.

3. Usage of educational technology and teaching technologies and increase the level of academic achievement among learners.

4. The current study explores the relation between the use of technology and techniques in education technology and teaching courses in general and the need for use in the computer course in particular.

\section{Tools}

1. In the current research the following tools were adopted:

2. A questionnaire describing the availability of educational technology innovations and techniques.

3. A questionnaire that describes the difficulties and obstacles of using educational technology innovations and techniques.

4. 4. Innovations and methods of educational technology.

5. An observation card which measures the performance abilities (developed by the 
author) of the use of technological innovations.

6. A test of achievement in the educational material stated (prepared by the author).

\section{Methodology}

The present research takes the quasi-experimental approach and descriptive procedure as necessary for the subject of the study. These techniques include dates, categorisation, explanation, analyses of previous studies and study. This approach is not limited to explaining the problem; all aspects and reasons of the problem are considered, evaluated and clarified, and some solutions are suggested. In addition, the current situation in Saudi Arabia's schools can be defined by the implementation of this approach.

\subsection{Sample:}

The study array comprises (42) students, (21) male students and (21) female students in public middle schools for the academic year (20152016).

\subsection{Limitations:}

The research involves students at schools where the practise of education is taught by the academic year's College of Specific Education (2015-2016) with students from the Education Technology division who use modern techniques in education technology.

\subsection{Hypotheses:}

1. There are no statistically significant differences at the $(\alpha \leq-0,05)$ level between the mean of the grades in the experimental group (teacher using technological innovation and technological techniques) and the average grades in the control group (teacher using the same conventional methods) for post-measurement of cognitive output following premeasurement.

2. 2. There are no statistically significant variations at the level of $(\alpha$ to 0,05$)$ between the average student scores in the experimental group (which are taught using technical advances and techniques) and the average student scores (which are taught in the same subject using the conventional method) after pre-measuring of cognitive efficiency.

3. 3. There are no statistically significant differences at the level of (alpha 0.05) between the mean of the scores of the students in the experimental group (who are taught using technological innovations and techniques) and the mean scores of the students in the control group (who are taught the same subject by conventional methods) in the post-measurement cognitive achievement after premeasurement.

4. 4. In the post-measurement of the cognitive achievement test at the level of study, there are no statistically significant differences at the level of (alpha 0.05) between the mean of the student scores in the experimental group (who are taught using technical advances and techniques) and the mean scores of students in the control group (who are taught the same subject by conventional methods).

\section{Procedures}

The surveys were issued to (60) randomly chosen teachers from (10) public middle and high schools.

Table (1) questionnaire distributed to the study sample

\begin{tabular}{|c|c|c|c|c|c|}
\hline Sample & $\begin{array}{c}\text { Distributed } \\
\text { questionnaires }\end{array}$ & $\begin{array}{c}\text { Returned } \\
\text { questionnaires }\end{array}$ & $\begin{array}{c}\text { Percentage of } \\
\text { Returned } \\
\text { questionnaires }\end{array}$ & $\begin{array}{c}\text { Excluded } \\
\text { questionnaires }\end{array}$ & $\begin{array}{c}\text { Completed } \\
\text { questionnaires }\end{array}$ \\
\hline $\begin{array}{c}\text { Computer } \\
\text { Teachers }\end{array}$ & 60 & 60 & $93.3 \%$ & 4 & 56 \\
\hline
\end{tabular}


Since the descriptive approach was implemented in the current study, a questionnaire and observation card were designed as a data collection and questionnaire tool, following the following procedures.:

First: designing the questionnaire:

The questionnaire was developed as one of the key tools of the study after reviewing many reports, research, books and periodicals, as most references to the importance of using innovation in educational technology have been made and some have theoretically defined the obstacles to using these innovations. The questionnaire was established in order to.

designing Steps of the questionnaire:

1- Identify objectives:

- Identifying the use in educational practise schools of innovation and techniques among student teachers.

- - Identifying the affordability of educational innovations and technology techniques in schools.

- Recognizing the obstacles and barriers to use educational technology innovations and techniques.

2- the questionnaire domains:

First field: the availability of innovations and techniques of educational technology is identified through the responses to the triple scale (highmedium-low).

Table (2) innovations and techniques of educational technology

\begin{tabular}{|c|c|}
\hline \multicolumn{2}{|c|}{$\begin{array}{c}\text { Innovations and techniques of educational } \\
\text { technology }\end{array}$} \\
\hline 1 & Network online and Global Information. \\
\hline 2 & the Internet Search engines. \\
\hline
\end{tabular}

\begin{tabular}{|c|l|}
\hline 3 & E-mail interaction. \\
\hline 4 & Conversation and Chat. \\
\hline 5 & Transfer files via Internet. \\
\hline 6 & Multimedia. \\
\hline 7 & Video conferencing. \\
\hline 8 & TV channels for Educational . \\
\hline 9 & Expert systems. \\
\hline 10 & Instruction Programming. \\
\hline 11 & Mobile Learning. \\
\hline 12 & Modules. \\
\hline 13 & Educational bags. \\
\hline 14 & E-Book. \\
\hline 15 & E- blackboard. \\
\hline
\end{tabular}

Second field: to assess the utilisation level of educational technology technologies and developments by reacting to the triple (highmedium-low scale of the fields listed above.

Third field: barriers and obstacles to the use of education technology technologies and developments. It comprises a list of obstacles that prevent the advantage of such creativity and education techniques. In addition to the possibility of voicing views and describing certain factors that impede the use of these technologies, each challenge has three levels (high- medium-low).

\section{3- Questionnaire Validity:}

The author sent the questionnaire to (11) faculty reviewers at several universities in the educational technology section..

\section{4- Questionnaire Reliability:}

To define both the reliability of the research instruments and of each region and the overall reliability of the study tools, Alpha Cronbach was adopted, as shown in the table below.

Table (3) Reliability coefficient of every domain of the questionnaire

\begin{tabular}{|c|c|c|}
\hline Domain & $\begin{array}{c}\text { No. of } \\
\text { paragraphs }\end{array}$ & $\begin{array}{c}\text { Alpha } \\
\text { Cronbach }\end{array}$ \\
\hline $\begin{array}{l}\text { 1. Development of educational technology } \\
\text { innovations and technology. }\end{array}$ & 9 & 0.8 \\
\hline $\begin{array}{l}\text { 2. Using of innovations and techniques of } \\
\text { educational technology. }\end{array}$ & 10 & 0.7 \\
\hline 3. Difficulties of utilizing innovations and & 18 & 0.8 \\
\hline
\end{tabular}




\begin{tabular}{|c|c|c|}
\hline techniques of educational technology. & & \\
\hline Total & 37 & 0.8 \\
\hline
\end{tabular}

The questionnaire reliability coefficient reached up to 0.8 , and the reliability coefficient for the different fields varied between (0.7) and (0.8).

\section{Second: Observation card:}

\section{1-Designing:}

The following steps were taken to assess the skills and effectiveness of using educational technology technologies and techniques:

- $\quad$ - Identifying the card's objectives: the card seeks to recognise the success of experts in education technology technologies and strategies at schools with teachings.

- - Identifying card content: the card contains (12) essential abilities for the use of educational technology technologies and techniques.

- - The skills instrument used in the observation card: the author created a list of main skills to be mastered by preservice teachers in relation to the axis and dimensions of the theoretic of the study while developing the skills list and drawing the corresponding sub-kills on a collection of factors to identify primary skills. - The following things: as shown in table (2).

\section{2- Observation card:}

The observation card was pressganged in the form of sequential, directly visible conduct skills after evaluating key competencies in sub-skills. Simplification and clarification were considered, short paragraphs were maintained, negative paragraphs were avoided, one output focused and action was made easy with this one. The card was composed of (53) skills.

\section{3- The observation card Designing:}

The object of the card was to include (12) the main competencies divided into the related (53) sub-competences in accordance with Annex (3).

\section{4- Observation card Reviewing:}

Presenting the card to a reviewers' group:

Reviewers also introduced to the wording of paragraphs several improvements which have had a profound effect on the final form of the Observation Card. Thus the card was validated.

\section{Reliability of the observation card:}

By consenting to the reviewer, Copper Equation was taken into account the reliability of the observation card. The agreement coefficient was then determined for each student. The author finds that the highest agreement coefficient is $(89,7)$, the lowest is $(86,46)$ and the mean is $(88,08)$ that confirms the instrument's reliability.

Third: Preparation of the achievement test:

In addition to defining the facets of learning, and creating an achievement trial through multifaceted choices and true or false questions, the goal would be to assess students' abilities with respect to recorder, knowing, evaluating and applying the contents of the academic course. The test originally consisted of (53) questions and 5 questions were omitted, after the Author and other reviewers had discussed these questions in the fields of education, teaching methods and assessment. (9 questions) to recall, (8 questions) to understand, (7 questions) to submit and (6) problems to examine. The remaining questions (41 questions) were discussed as follows. For every correct answer, one point was decided. The test has been used to identify the time and reliability of a sample of students at the College of Education.

The coefficients of easiness and complexity were established in the test questions (Zaytoun, 2001) and the reliability coefficient reached (0.86). The validity of the intrinsic test was determined and (0.89) was appropriate after verification of the material validity.

Identify the vocabulary of the test: the author found that by reviewing previous research, such as Al-Agami (2004), Al-Khawaleda (2003), Abu Zayd (2003) and Al-Lazzam (2002), most previous studies have used quantitative language and have avoided subjectivity in the correction process. 
A number of studies were considered, including Dwidri (2003), Ali (2002), Al-Oumariya (2005) and Al-Qadi (2002), which examined the assessment methods in general and in particular, the objective measures, as well as the criteria to be followed for a successful test.

Vocabulary analysis and editing: Test vocabulary is checked after an adequate drafting period to ensure that the context and overlap that could impact the achievement of the trial target was free of complications.

Identify the final number of exam vocabulary: the examination includes questions with a view to the testers' views and suggestions (31). The objective of each question is to measure an educational objective; since at the four cognitive levels (remembering, comprehension, implementation

first student + last one

the test time $=$ and analysis), more than one problem will measure one objective at each level.

Test instructions: the instructions attempt to clarify the test ides in as straightforward a way as possible and should thus be transparent and succinct in drawing up such instructions.

The test correcting method: every correct question is marked, since the test involves (16) multiple vocabularies in its original form and (15) true and false vocabularies, so the maximum score is (31) and the minimum is $(0)$.

Application for the test: an exploratory sample of (15) students was submitted in its original form after preparation of the test, which was different from those included in the test sample.

achievement time for the test: the required time for the performance test using the following AlHuzaifi equation (2003):

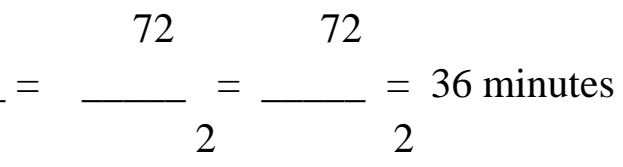

The first student's time was (32) minutes; the latter student spent (53) minutes, and the overall test time was (36) minutes by measuring the mean.

Success test Reliability: after applying the performance test to the students of the test sample, one score was given to correct their answers to the test vocabulary and null to the wrong answer. The test was accurate $(0,84)$, a value that makes it possible to use the test as an instrument to assess students' cognitive efficiency, thereby obtaining trustworthy results.

The validity of reviewers: Obaidat and other researchers (2003) indicate, if they emphasise that the test meets their objectives, the validity of reviewers can be assessed through the presentation of the test to a variety of specialists and experts in the target area.

First: results of Pre-application

The T-test was already implemented, following an estimate for integer averages and a standard deviation, according to Table (4) below, After gathering information for the academic achievement test from the preview of an experimental and control sample and ensuring sample accuracy.

Table (4): results of the analysis of the pre-achievement test

\begin{tabular}{|c|c|c|c|c|c|c|}
\hline Group & $\begin{array}{c}\text { No. of } \\
\text { students }\end{array}$ & Mean & SD & FD & $\begin{array}{c}(\mathrm{T}) \\
\text { Value }\end{array}$ & Sig \\
\hline Control & 22 & 50,0 & 89,0 & \multirow[t]{2}{*}{38} & \multirow[t]{2}{*}{17,0} & 83,0 \\
\hline Experimental & 22 & 45,0 & 1.87 & & & $\begin{array}{l}\text { Statistically } \\
\text { insignificant }\end{array}$ \\
\hline
\end{tabular}


Table (4) shows that the measured value (T) is statistically negligible, and no substantial difference occurs before implementation of the techniques or developments between the experimental achievements and control groups, which stresses continuity and equal value between these two groups in terms of the education material before application.

Second: results of Post-application:

Table (5) Results of post-application and (T) Value in the academic achievement test among students from both groups

\begin{tabular}{|c|c|c|c|c|}
\hline Group & No. & M & SD & T \\
\hline Experimental & 22 & 42.11 & 3.41 & 6.3 \\
Control & 22 & 38.91 & 4.61 & $\begin{array}{c}\text { Significant at } \\
00.05\end{array}$ \\
\hline
\end{tabular}

Table (5) indicates that the calculized value (T) (6.3) is statistically significant in terms of the amount of 0.5 , emphasising that the average category that adopts innovation and educational technology techniques in line with prior studies. Table (5) also provides the results from (T) research to define, with a view to documenting, understanding, implementation and study the student score, both experimental and control classes, is statistically significant to the former

effects of pre- and post-application techniques and developments. The following is clarified:

First: remembering:

Table (7): Calculating the mean and standard deviation of the arithmetic as well as the values of (T) and their significance at the stage of remembrance

\begin{tabular}{|c|c|c|c|c|c|c|}
\hline \multirow{2}{*}{ Domain } & Application & No. & M & SD & "T" & Sig \\
\hline \multirow{2}{*}{ Remembering } & Pre & 22 & 61.2 & 76.1 & \multirow{2}{*}{82.22} & 00.01 \\
\cline { 2 - 7 } & Post & 22 & 94.12 & 07.2 & \\
\hline
\end{tabular}

pre/post implementation of the achievement test at the memory level, the results of the experimental population differ statistically substantially in favour of post-application, thereby rejecting the first experimental hypothesis in the current analysis.

\section{Second: Understanding:}

Table (7) checking the validity of the initial hypothesis for the current study that shows that the mean results of the student in the two groups do not vary statistically significantly, indicates that (94.12) is higher than that of the postapplication (2.61) and 22.82 is greater than the estimated value of the " $\mathrm{T}$ " This shows that in the

Table (8) Calculating the mean and standard deviation of arithmetic as well as the values of (T) and their meaning at the level of Understanding

\begin{tabular}{|c|c|c|c|c|c|c|}
\hline \multirow{2}{*}{ Domain } & Application & No. & M & SD & "T" & \multirow{2}{*}{ Sig } \\
\hline \multirow{2}{*}{ Understanding } & Pre & 22 & 2.58 & 1,46 & \multirow{2}{*}{12.21} & 00.01 \\
\cline { 2 - 7 } & Post & 22 & 8.08 & 2.27 & \\
\hline
\end{tabular}

Table (8) tests the validity of the second hypothesis, which indicates that there is no statistically significant difference between the average performance of students who are trained 
in innovations and techniques and those who are trained to assess the degree of comprehension of academic achievement by traditional methods (8.0); the calculated value 'T' (12.21) is greater than the tabulated value ' $\mathrm{T}$ ' (8.0). The second hypothesis of the present study is also rejected.

Third: Application

Table (9): Calculation of the mean and standard deviation arithmetic as well as (T) values and their importance at the application level

\begin{tabular}{|c|c|c|c|c|c|c|}
\hline \multirow{2}{*}{ Domain } & Application & No. & M & SD & "T" & Sig \\
\hline \multirow{2}{*}{ Application } & Pre & 22 & 1.75 & 1.13 & \multirow{2}{*}{15.50} & 0.01 \\
\cline { 2 - 7 } & Post & 22 & 44.6 & 1.42 & \\
\hline
\end{tabular}

Table (9) which explores the effectiveness of a third hypothesis that indicates that the average number of experimental students who are instructed by innovation and education technology technics do not vary statistically significantly, and that of the control team, instructed by the standard method for pre- and post-application testing of the academic system. The estimated " $\mathrm{T}$ " value, which exhibits $(15,50)$, is higher than the tabulated $\mathrm{T}$ value, which (457.2 to 05.0) means that the average student scores in the application before and after are statistically substantially different for the application. The third hypothesis is also rejected in the present study.

Fourth: Analysis

Table (10): Calculation of the mean and standard deviation arithmetic as well as (T) values and their importance at the Analysis level

\begin{tabular}{|l|c|c|c|c|c|c|}
\hline \multirow{2}{*}{ Domain } & Application & No. & M & SD & "T" & sig \\
\hline \multirow{2}{*}{ Analysis } & Pre & 22 & 1.52 & 0.94 & \multirow{2}{*}{7.63} & 0.01 \\
\cline { 2 - 7 } & Post & 22 & 3.47 & 1.21 & \\
\hline
\end{tabular}

The validity of the fourth statement is discussed in table (10), which shows that the mean values of experimental group students who are instructed by innovation and educational technology techniques do not differ statistically significantly from those of the control team who are instructed by the traditional pre-and-after approach to evaluating the academic method .The calculized value of $\mathrm{T}^{\prime \prime}$
(7.63), which exceeds $T$ value (457.2 to 05.0 ) of output between ÚFA, thus implies that the mean number of students at the pre-and-post application level in favour of the post-application is statistically substantially different. The fourth hypothesis of this analysis is also rejected.

Fifth: the achievement test Dimensions

Table (11): Calculation of the mean and standard deviation arithmetic as well as (T) values and their importance at all the achievement levels

\begin{tabular}{|c|c|c|c|c|c|c|}
\hline Level & $\begin{array}{c}\text { Applicati } \\
\text { on }\end{array}$ & No. & M & SD & "T" & Sig. \\
\hline Total=(remembering, \\
$\begin{array}{c}\text { understanding, } \\
\text { application, analysis) }\end{array}$ & Pre & 22 & 8.53 & 3.38 & 20.22 & .01 \\
\cline { 2 - 7 } & Post & 22 & 30.94 & 5.03 & \\
\hline
\end{tabular}


Table (11), which discusses the validity of the fifth hypothesis, which states that the median scores of students in the experimental community who have been trained in innovative and technological techniques and those in the control group who have been trained in the traditional method in the pre-and-post application to assess the total Table (11) Table The approximate ' $\mathrm{T}$ ' value (20.22) is higher than the tabulated $\mathrm{T}$ value (457.2 to 0 ). The 5 th hypothesis in the current analysis is also rejected.

The results can be explained as follows:

- - While the arithmetic means of both groups are identical in terms of their success test outcomes, variations have been preferred by the experimental community. Such proximity may be due to the method of analysis and the nature of performance reviews, which involve recalling information. However the findings indicate the efficacy of education technology advances and techniques in improving academic achievement among experimental sample participants by providing instructers with knowledge as well as providing instructors with the opportunity for students to explore concepts of the subject they are concerned with. This is in addition to the students' activity book, which helps students more optimistic and takes down their notes during the study period.

- The findings further show that the fourstage academic performance (recall, understand, apply and analyze) can only be due to the use of technologies and education strategies to improve their level of academic achievement in the experimental-group studies. - However in the conventional methods and the theoretical context, the control group relies on the content of academic courses.

- Writing in the activity book encourages learners to gain information by selfstudying, which is further stressed in terms of their attitudes and their constructive involvement in the learning process when applying, making learning productive in turn and skills development easier. The second hypothesis of the present study is therefore dismissed.

\section{Effect size:}

Eta-squared - in order to determine the effect size of the independent variable (use of technology and innovations) on the dependent variable (academic performance), a cumulative D-value is measured. Table (12) shows these results.

\begin{tabular}{|c|c|c|c|c|c|}
\hline Item & DF & T-value & $" \square \square "$ & D-value & Effect size \\
\hline Test & 42 & 21.53 & 0.916 & 6.60 & High \\
\hline
\end{tabular}

Table (11) shows that 0,916 and 6,60 (D) value reached above $(0,8)$ are higher. This shows that "technologies and inventions" are the independent variable which has important consequences for academic achievement.

${ }^{2} \mathrm{~T} \quad$ Square root of $\left({ }^{2} \mathbf{h}\right) * 2$

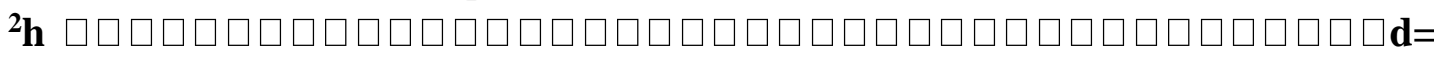

$$
{ }^{2} \mathrm{~T}+\mathrm{DF} \quad \text { Square root of }\left({ }^{\mathbf{2}} \mathbf{h} \mathbf{- 1}\right)
$$

This made the fifth hypothesis of the current analysis, which showed that the mean student scores in both experimental and control groups in the post-performance test for the experimental group do not vary statistically significantly at $(\alpha$ $\leq 0,05)$.

8. Conclusion 
1. The study concluded that as the general arithmetic mean stretches to 2.7 , there is little availability of innovations and technology in education schools for young and older student teachers.

2. The student teachers of the educational practise are faced with difficulties in using technologies and educational technology tools since the general arithmetic mean of the problem level exceeds 1.44.

3. The capacity of student teachers to use the technologies and technology of education is limited, provided that the arithmetic mean is 1.34 .

\section{Recommendations}

- Practice in education is the connection between the academic and the educational aspects. Learners' training must address all facets, in order to adapt the training courses to the preferences, characteristics and needs of students. This means that the training plan must also cover all aspects and details of the scientific component that allows teachers to master their courses.

- The Ministry of Education must provide educational technology innovations in all the schools, particularly secondary and middle schools..

- Some experts and professionals must be hired to provide training on education technology technologies, keeping in mind that some managers were not mainly trainers that could turn income training into unsuccessful teachings.

- A manual on the use of education strategies should be created to include rules on the content collection and rules to be taken into account before during and after use.

- All the opportunities for the use of technical advances must be furnished to schools in a suitable way.

- In the light of this, both educational and academic aspects need to be incorporated into the education process by education, which is considered the meeting point between the two aspects.

- The training is the means by which the teaching attitudes of students are shaped and by which teachers obtain the requisite teaching qualifications. Via continuous and severe preparation, student teachers gain the teaching rules during the time of their education.

- The instructional activity is how student teachers can define strategies for addressing problems and familiarise themselves with current relationships in the education environment to learn about the rules and regulations that are needed to ensure that the education process moves in the right direction.

- Practice in education allows teachers to familiarise themselves with critical problems that are raised in the educational process so that students can have knowledge and experience to make them effective and active in society in the future. To this end, a set of recommendations are given in the current research:

- Prepare and establish curriculum services in collaboration with colleges for specialised programmes and different educational fields.

- To give students the educational method and strategies that enable them to excel in teaching through classes, forums and seminars that contribute to teaching strategies, improve management efficiency and upgrade educational methods implemented at the colleges.

- Establish an assessment framework for students, evaluate test outcomes and draw up suitable reports with the participation of specialist centres.

- Offer suggestions and recommendations for improving and maximising the effectiveness of the implementation criteria of the education programme based on graduate assessment performance. 
- Unify preparation, design, assessment, creation and follow-up processes for educational programmes and courses in universities.

\section{Suggestions for future research:}

1. Attitudes of teachers regarding the use of instructional technology innovations.

2. Comparative research between the effects on academic performance of students from conventional educational approaches and modern teaching techniques.

3. Conduct related research at other stages of education.

\section{References:}

[1] Abdel-Karim, Y. B. (2006). Change in the organizations of contemporary works through the total quality management. Algeria, University of Abou Bekr Belkaid.

[2] Abdel-Megid, M. M. (2000). Science instructors' awareness of innovations of educational technology and their attitude towards their utilization. The Egyptian Association for Educational Practicum: the Fourth Scientific Conference, Educational Practicum for all (31 July- 13 August), (1), p. 309.

[3] Al-Gabry, N. A. (2009). Evaluation of academic performance among students of Teba University in Saudi Arabia. AlKhaleej Al-Arabi Journal, Arab Bureau of Education for the Gulf Indicates, (111).

[4] Al-Ghadeer, F. E. (2002). Adopting innovations of educational technology in teaching in the schools of Saudi Arabia: an evaluation study. Cairo University: Educational Studies Institute.

[5] Al-Ghadeer, F. E. (2009). Adopting innovations of educational technology in teaching in the schools of Saudi Arabia: an evaluation study.

[6] Al-Harbi, M. B. (2007). Requirements of using e-learning in teaching Mathematics for the secondary stage from the perspective of specialists. Unpublished
PHD thesis, College of Education, Umm Al-Qura University.

[7] Ali, A. H. (2001). Learning and academic achievement and their relation to the family (1st ed). Skills Development Center, Foundation of Technical Education. Al-Kanadi, S. B. (2005). The reality of utilizing the modern education techniques and challenges facing instructors in public schools in Amman. A study presented to the General Administration for Education in Ash Sharqiyah Region. p.6.

[8] Al-Khayyat, A. M., \& Al-Agami, A. K. (2001). The effect of utilizing educational technology on promoting the academic achievement skills among primary school students. Unpublished MA thesis. College of Education, Assiut University. Amin, Z. M. (2000). Problems relating to educational technology. Minia: Dar AlHuda. Anderson (2001). Using Multimedia in Education , Mc Hill , 2001 , P 89

[9] Asettea (2005). Internet usage in Education. Technological Horizon In education Vol 1 P 27 Atwa, G. E. (2001). Educational administration and pedagogical supervision: principles and application (1st ed.). Jordan: International Scientific House \& Culture House. Conference of education and society held in the College of Education in Damietta. (2003). Published in the Journal of the College of Education, (43), pp. 123- 149.

[10] FathAllah, M. A. (2004). Foundations of producing and using the methods of educational technology. Riyadh: Dar AlSamie'i.

[11] Halas, D. D. (2011). Educational practicum in Palestinian Universities (concept- significanceobjectivesdimensions- phases). College of Education- Islamic University- Al-Azhar University, Gaza.

[12] Hamed, A. E. (2004). A study of the key problems facing student teahcers during 
the educational practicum period in the College of Education \& Basic Sciences. The Educational Journal of Sciences, Ajman University of Science and Technology, (3), pp. 143-181

[13] Hankey, S., Longley, T., Tuszynski, M., Ganesh, M.I (2013). Visualizing Information for Advocacy. The Tactical Technolog Collective, Bangalore, India (2013).

[14] Ibn Manzour, A. G. (1985). Lesan al-Arab (Vol. 4). Beirut: Dar Ehyaa' Al-Turath.

[15] Kariuki, P. \& Paulson, R. (2006). The effects of computer animated dissection versus preserved animal dissection on the student achievement in a high school biology class U. S. ; Tennessee. Eric Document No: ED460018.

[16] Khadr, F. R. (2006). Teaching methods of social studies. Amman: Dar e-Sira for Publishing and Distribution.

[17] Khamees, M. A. (2003). Products of educational technology. Cairo: Dar AlHekma.

[18] Kotler (2001). ph\&Armstrong,G.2001:Principles of marketing ninth edition,U.S.A, Prentice Hall.

[19] Kuh, G. D., et al. (2006). Student's success in the university: fostering adequate climate (Al-Emam, M, Trans.). Riyadh: Obeikan Library.

[20] Leite, Walter L, Svinicki, Marilla; and Shi, Yuying (2009). Attempted Validation of the Scores of the VARK: Learning Styles Inventory With Multitrait-Multimethod Confirmatory Factor Analysis Models, pg. 2. SAGE Publications, 2009.

[21] Miller, P. (2001). Learning styles: The multimedia of the mind. ED 451340.

[22] Ministry of Communication \& Information Technology. (2005). The National Plan for Communication and Information Technology. p. 36. Accessed on 9\12\2008. Retrieved from http://www.mcit.gov.sa/ arabic/NICTP/Policy/

[23] Pavla Kovařova and Gabriela Šimkova (2014). Evidence-Based Learning Approach in Evaluation of Information Literacy Education, Masaryk University, Faculty of Arts, Division of Information and Library Studies, Brno, Czech Republic,

\{kovarova,gsimkova\}@phil.muni.cz, pp. 560-569.

[24] Pınar Nuhoğlu Kibar and Buket Akkoyunlu (2014). A New Approach to Equip Students with Visual Literacy Skills: Use of Infographics in Education, Hacettepe University, Faculty of Education, Department of Computer Education and Instructional Technology, (Eds.): ECIL 2014, CCIS 492, pp. 56-65, 2014.

[25] Rashwan, H. A. (2005). Education and the society. The University Youth Foundation, Alexandria. p.33.

[26] Reiser, R.A (2002) What Field Did You Say You were in? Defining and Naming Our Field. In: Reiser, R.A., Dempsey, I.V. (eds.) Trends and Issues in Instructional Design and Technology, pp. 5-15. Merrill/Prentice-Hall, Upper Saddle River (2002).

[27] Romisofisky, A. G. (n.d.). Selection and utilization of educational methods according to the systems approach (AlArabi, S. A. \&Al-Qula, F., Trans.). The Arab Organization for Education and Culture, Kuwait.

[28] Roob, A.G. (2001). Effective of Using Web in Education With An Experience, University of Salzbura, 2001 P 201

[29] Salem, M. M. \& Al-Halibi, A. B. (1998). Field education and basics of teaching (2nd ed). Obeikan Library.

[30] Zaytoun, H. H. (2001). Teaching skills. Cairo: Alam Al Kotob. http://www.ahewar.org/debat/show.art.asp ?aid=251906 
http://elearning.iugaza.edu.ps/emag/article.

php?artID=41\#sthash.NEo6W1Is.dpuf 